\title{
The DP-cycle in Hungarian and the functional extension of the noun phrase
}

\author{
BARBARA EGEDI
}

\subsection{Introduction}

The first impression might be deceptive, and it is indeed so if one looks through the overall history of Hungarian nominal expressions. The inner structure of the noun phrase has not changed a lot, at least as compared to some other phenomena on the sentential level. The order of the major constituents seems to be the same, as far as the order of the modifiers and the modified elements is concerned, and the possessive constructions also appear to have been used in the first written sources in the same manner as in Modern Hungarian. The most significant change is the emergence of the definite article, the exact date of which cannot be determined. The article seems to be attested as early as the first continuous text records appear, admitting that its use was considerably different from the way it functions in Modern Hungarian. The gradual expansion of the definite article can, however, be well observed in the historical stages and it undoubtedly had important structural consequences at the nominal left periphery. The aim of this chapter is to follow, describe, and analyze these interrelated phenomena, namely the emergence of the article, its functional expansion, the various strategies for the renewal of the demonstrative system, and the rearrangement of the leftmost peripheral position within the noun phrase; to put it differently, the DP-cycle in Hungarian and its consequences at the nominal left periphery.

In section 3.2 the marking of definiteness will be addressed beginning with a general discussion of the phenomenon. This is followed by a more specific survey of definiteness marking in Proto-Hungarian as well as in Early and Late Old Hungarian. Section 3.3 is concerned with the DP-cycle, more precisely with the problem as to how the demonstrative system was renewed after the definite article had grammaticalized. 
It will be shown that in Hungarian, the renewal of the demonstratives involves at least two types of strategies (reinforcement and determiner doubling). The structural reanalysis of determiner doubling (from adjunction to a DP-internal specifier position) that took place in Middle and Modern Hungarian is also discussed. Section 3.4 presents how the competing strategies of demonstrative modification coexist from the Middle Hungarian period onward and what their descendant constructions in present-day Hungarian look like. This part will be complemented by an inspection of some dialectal peculiarities. The chapter relies heavily on corpus queries carried out in the recently developed (and still developing) Old Hungarian corpus. The chapter is concluded by summarizing the results.

\subsection{Marking of definiteness in Old Hungarian}

\subsubsection{About definiteness and its marking}

In this chapter, definiteness is conceived and used in terms of the basic pragmatic notion of identifiability. According to this notion, the speaker signals that the hearer is able to assign a referent to a certain noun phrase. ${ }^{1}$ The hearer can identify the referent either because it is already accessible in the context, or it can be associated with another discourse referent present in the context, or the reference is clearly identifiable or inherently unique by the shared knowledge of the interlocutors in a given speech situation. ${ }^{2}$

Although the category of identifiability and, as a consequence, the semantic and pragmatic notion of definiteness can be assumed to be universal, its grammatical realization is a language-specific property. The definite article is the grammaticalization proper of the semantic and pragmatic concept of definiteness, but many languages lack this type of grammatical element. Definiteness can be encoded in several alternative ways, for instance by positional ordering, special case-marking, or verbal conjugation. Even in languages that make use of the definite article, its relative frequency or the contexts in which the article appears are not necessarily identical.

The grammatical encoding of referential identification may segment the semantic field at different points in different languages, i.e. there is great variation as to how extensive the ground covered by the category of definiteness is within the semantic/pragmatic field in a language. Accordingly, this semantic range may even change in time (Lyons 1999: 336-337). In a language documented long enough for a

1 For definitions and properties of definiteness (e.g., uniqueness, inclusiveness, familiarity), consult first of all chapters 1 and 7 of Lyons (1999), and Alexiadou et al. (2007: 51-157). For different approaches and concepts characterizing definite descriptions, see also Abbott (2004).

2 As Hawkins (1991) claims in a detailed pragmatic account, existence and uniqueness of a definite description must hold within the universe of discourse or a subset of it, which can be inferred by the hearer through specific pragmatic parameters. For similar approaches, see Westerståhl's (1985) context sets, and Roberts' (2003) informational uniqueness relative to the discourse situation. 
diachronic investigation, one can observe how the grammatical encoding of referentiality changes gradually and what factors influence the process. Gradualness is an important feature in the case of Hungarian, too. When the definite article emerged, it first only appeared in the constructions where the referent of the noun phrase was not anchored in another way. To put it differently, the early variant of the Hungarian definite article encoded pragmatic definiteness only-as will be explicated in section 3.2.4.

When the definite article emerges in a language, as a result of grammaticalization, it is not uncommon that the first attestations remain uncertain or ambiguous for a longer period. The source category begins to fulfil a new function, but its formal properties do not necessarily change immediately, and the two related constructions may appear to remain structurally homophonic. ${ }^{3}$ As in so many other languages, the Hungarian definite article developed from the distal demonstrative, but the time of this functional split is uncertain. In Old Hungarian the article and the distal demonstrative look identical, share a phrase-initial prenominal position, and even overlap functionally (e.g., in anaphoric use). Relevant data only survived in writing, so even if the simple definite noun phrases and those modified by a demonstrative were distinguished by different intonational properties from the very beginning, in absence of its graphic marking, it is impossible to test. This kind of uncertainty in identifying early uses of the article shows up in describing the historical changes in other languages as well, where the formal and distributional criteria are not sufficient to distinguish between the canonical and the article-like uses of a demonstrative (for the same problem in Old English, see Sommerer 2011: 183-209).

To identify the Old Hungarian definite article, special semantic and pragmatic contexts must be examined in which the determiner in question appears regularly and in which it can hardly be interpreted as a demonstrative. As Nikolaus Himmelmann (2001: 833-834) points out, building on Hawkins' (1978) systematic presentation of article use in English, demonstratives must not be used in certain semantic and pragmatic contexts in which articles consistently appear. Such contexts are the larger situation use ("the first mention of entities that are considered to be unique, hence generally identifiable, in a given speech community") and the associative-anaphoric use ("the first mention of an entity that is not unique per se but with respect to a previously mentioned referent"). This approach turned out to be quite feasible in identifying Old Hungarian determiners, but the method obviously needs satisfactory contexts to apply. Unfortunately, the earliest article-like uses of the distal demonstrative remain ambiguous due to the nature of the texts in which they appear, as will be shown in section 3.2.3.

\footnotetext{
3 It is a general observation made on grammaticalization processes that change in meaning and in use tend to precede a change in form (cf. Heine, Claudi, and Hünemeyer 1991: 212-213).
} 


\subsubsection{What can be said about definiteness marking in Proto-Hungarian?}

Before the end of the 12th century we have no continuous written sources in Hungarian. Any hypothesis about Hungarian syntax before that date can only be formed by means of reconstruction based on the evidence that the sister languages providewhich themselves had not been documented before the 19th century.

According to the generally accepted view in the descriptive literature, the Hungarian definite article is the result of an internal development (Simonyi 1914: 68-69; Klemm 1928: 317; D. Mátai 2003: 419-420), which reasonably conforms to the fact that Uralic languages in general have no definite article at all. Exceptions to this tendency are, besides Hungarian, the Mordvin language, where a definite vs. indefinite declension developed (Zaicz 1998: 191-193) and Finnish, in which the emergence of the article is a fairly recent phenomenon and seems to be taking place currently in the spoken language variety (Laury 1997). Although the exact time of grammaticalization of the Hungarian article is impossible to tell, it must have taken place at the beginning of the Early Old Hungarian period or even before, during Proto-Hungarian. The change in definiteness marking was probably not independent of other, more general structural changes on the sentence level, which finally led to the characteristic discourse-configurational word order patterns of Hungarian (See sections 2.2 and 2.3 in the previous chapter and É. Kiss 2013 on this matter). But what can be said about the determination system in Proto-Hungarian before this new strategy emerged?

It has long been observed and described that in most of the Uralic languages possessive affixes (primarily the 3 rd person singular form) are frequently and quite regularly used to mark the definiteness of the noun, without expressing any kind of possessive relationship. It seems to be generally agreed on that this non-possessive function of the possessive affixes $(\mathrm{Px})$ corresponds to that of the definite article in Indo-European languages. ${ }^{4}$ Irina Nikolaeva (2003) argues for a more complex explanation of the function these possessive affixes fulfil. According to her analysis, $\mathrm{Px}$ may indeed express identifiability as far as the 3 rd person singular form is concerned; its use, however, is not obligatory. At the same time, the 1st and 2nd person singulars in non-possessive meaning rather serve to link the referent of the noun phrase to the participants of the actual speech act. Somewhat similarly, Kari Fraurud's insightful study (2001) concludes that associativity is more essential than referentiality when one aims to find the common feature of a wide range of non-possessive uses of $\mathrm{Px}$ in different languages. That is why these special possessive clitics/affixes show a remarkable formal and functional stability in time, and do not necessarily develop into an article. Moreover, nothing prevents demonstratives from appearing in articlelike uses in these languages; they may step on a grammaticalizational path that finally leads to the birth of a definite article, independently of the extended uses of

\footnotetext{
${ }^{4}$ Cf. inter alia Collinder (1960: 203-204, \$616); See also Künnap (2004) for a general survey of the phenomenon in various Uralic languages. One may find a good source of examples in Nikolaeva (2003).
} 
the Px. This observation is essential considering that the Hungarian definite article indubitably developed from a demonstrative, but we do not want to exclude the possibility that possessive affixes were also used for determination (more precisely, for referential anchoring) in an earlier stage of the language.

It is to be noted that the determiner function of possessive affixes has been suggested to be a feature already present in Proto-Uralic (Décsy 1990: 81). Taking into consideration that the Ob-Ugric languages, the closest relatives of Hungarian, presentday Khanty (Ostyak) and Mansi (Vogul) also share this property, it is highly probable that Proto-Hungarian Px inherited this feature but, during its separate life, lost it at a certain point. As a matter of fact, such a use of possessive suffixes cannot be proved for Hungarian. Only a few morphological remnants suggest that the function of Px once might have been more complex than it is today. For instance, it is remarkable that the accusative form of personal pronouns in first and second persons always includes an apparently redundant Px, as can be observed in the contrastive Table 3.1. This might be the relic of a more productive marking of definite objects in Proto-Hungarian. (For the absence of the accusative ending - $t$ in certain cells of the paradigm, see section 2.2.2. in Chapter 2.)

(1) engem, téged, minket, titeket 'me, you, us, you ${ }_{\mathrm{PL}}$ ' (accusative series)

TABLE 3.1. Personal pronouns in nominative and accusative

\begin{tabular}{|c|c|c|c|c|}
\hline & \multicolumn{2}{|c|}{ nominative } & \multicolumn{2}{|c|}{ accusative } \\
\hline & singular & plural & singular & plural \\
\hline \multirow[t]{2}{*}{ first person } & én & $\mathrm{mi}$ & en-g-em- $\varnothing$ & mi-nk-et \\
\hline & & & I-EP-1SG & we-1PL-ACC \\
\hline \multirow[t]{2}{*}{ second person } & te & $\mathrm{ti}$ & té-g-ed- $\varnothing$ & ti-tek-et \\
\hline & & & you $_{S G}-E P-2 S G$ & you $_{P L}-2 P L-A C C$ \\
\hline
\end{tabular}

There are also some odd expressions, primarily occurring in spoken registers, in which a non-possessive Px is used ${ }^{5}$ to express an (often negative or degrading) emotional attitude of the speaker towards the referent of the noun phrase. Consider the following examples:

(2) a. a hülyé-je the stupid-3sG 'this stupid one' b. a szemtelen-je the shameless-3SG 'this shameless one' c. a csóró-ja the blighter-3sG 'this blighter'

5 This observation has been made by Katalin É. Kiss (p.c.). 
Nevertheless, the determiner use of possessive suffixes in a systematic and productive way remains merely hypothetical, since in the first linguistic records, e.g. in the Funeral Sermon and Prayer (ca.1195), there is no trace of the non-possessive use of possessive suffixes. At the same time, the determiner $a z$ ('that') already seems to function more like a definite article.

\subsubsection{Is there a definite article in Early Old Hungarian?}

The question formed in the above title is not a trivial one. The use and distribution of the article in the earliest codices from the Late Old Hungarian period show a considerable difference with respect to the modern system of determination, which needs some explanation, but the existence of a true, grammaticalized article in the period of the codices is undeniable (see the next section). At the same time, the article status of the definite determiners in the Early Old Hungarian sources cannot be justified with certainty, and the very first attestations of the article, or more precisely the earliest article-like uses of demonstratives, remain uncertain.

As has already been pointed out, when the demonstrative functionally split into a deictic determiner and a simple definite article, the formal and distributional properties of the two elements did not diverge immediately. In many cases, the interpretation of the determiners is ambiguous for today's reader since they have identical forms, share the same prenominal position, and they even functionally overlap, e.g., in their direct anaphoric use. Special semantic and pragmatic contexts in which only articles can appear may help to decide the question, but in the Early Old Hungarian records the textual contexts are simply not as ample as would be necessary for disambiguation. The majority of the Early Old Hungarian sources are short and not continuous. They are principally names of people and places and glosses embedded in Greek or Latin documents and charters. ${ }^{6}$ Isolated words or phrases are obviously inadequate for a syntactic analysis. The first continuous texts from the same period (listed in Table 3.2) are traditionally grouped together and labeled as "shorter text records from the age of the Árpád dynasty", but these texts, in reality, do not form a uniform corpus either

TABLE 3.2. Text records from the age of the Árpád dynasty

\begin{tabular}{ll}
\hline Manuscript & Date \\
\hline $\begin{array}{l}\text { Funeral Sermon and Prayer } \\
\text { The Königsberg Fragment and Ribbons }\end{array}$ & $\begin{array}{l}\text { ca.1195 } \\
\text { end of 12th c. - beginning of 13th c. } \\
\text { The Old Hungarian Lamentations of Mary } \\
\text { second half of 13th c. } \\
\text { Gyulafehérvár Lines }\end{array}$ \\
\hline
\end{tabular}

6 The first charter that contains a considerable amount of Hungarian words and word-groups is the Letter of Foundation of the Tihany Abbey, which can be dated to 1055. 
in time or in space. They are actually very short (tokens will be given in Table 3.3). One of them is very fragmentary (The Königsberg Fragment and Ribbons), as it was found reused in the binding of another codex. The Lamentations of Mary is written in verse. The Gyulafehérvár Lines cannot even be considered as a coherent text, being composed of 15 juxtaposed noun phrases which are not embedded in sentences.

In these texts, the number of the cases in which definite determiners appear and their function might be examined is small. Lamentations of Mary has no such case at all. The phrase of the Gyulafehérvár Lines in (3) very probably has an article before the complex participial modifier of the noun, but the whole phrase is isolated, a member of a list, so the precise nature of its use cannot be defined for lack of context. The "articlehood" of the determiner in (4) cited from the Königsberg Fragment and Ribbons is more debatable: the function is clearly cataphoric, and as such appropriate for a demonstrative as well. Moreover, the lexeme for God (ysten) is inherently unique by nature and this noun type consistently resists being determined, at least in the period of the first codices.

(3) oz kerezt fan figeu kepeben

the/that cross wood-suB hanging picture-Poss-INE

'in his form of hanging on the cross'

(Gyulafehérvár Lines)

(4) de qui legen neky atia ozut nem

but who be-SBJV DAT-3SG father-Poss.3SG that-ACC not

tud $^{\text {hotiuc }} \quad \mathrm{Ez}$ oz $\quad$ ysten mynt, evt esmeríuc quit sceplev

know-PossiB-1PL this the/that god as him know-1PL whom spot

nem illethet.

not concern-POssiB.3SG

'But who would be his father, we cannot say. This is the/that God as we know him who is immaculate.'

(The Königsberg Fragment and Ribbons)

The determiner $o z$ 'that' occurs four times in the Funeral Sermon and Prayer, and the contexts of its uses are clear. In the previous discourse, God barred Adam only from the fruit of a single tree in Paradise. The first mention of this particular fruit is embedded in a possessive structure. Thus, there is no need for any determiner (see the discussion below). At the second mention, the determiner $o z$ appears (5), which can be interpreted either as a demonstrative or as a definite article because it indicates a direct anaphor. The third and fourth mentions of the same fruit (6), as well as the fifth (7), are still anaphoric, but the clear coherence of the text makes a demonstrative interpretation redundant. These latter uses are much closer to what a definite article is supposed to do: the determiners simply identify the referent of the noun phrases as present in the discourse without any deictic or locative force. ${ }^{7}$

\footnotetext{
7 For the detailed presentation of all these early cases with an overview of the previous literature on the matter, written in Hungarian, see Benkő (1980: 258-260). Loránd Benkő himself admits that based on this scarcity of data one can hardly form a definitive opinion about the use of the definite article in the period as a whole.
} 
(5) ysa kí nopun emdul oz gimilstwl halalnec indeed which day-SuP eat.MOD.2SG the/that fruit-ABL death-DAT halalál holz

death-Poss-INS die-2sG

'Indeed, the day when you eat from that/the fruit, you will die the death of deaths.'

(Funeral Sermon and Prayer)

(6) es evec oz tiluvt gimilstwl. es oz gimilsben and eat-PST.3SG the/that forbidden fruit-ABL and the/that fruit-INE

halalut evec.

death-ACC eat-PST.3SG

'and he ate from the/that forbidden fruit and in the/that fruit he ate death'

(Funeral Sermon and Prayer)

(7) Es oz gimilsnec wl keseruv uola vize

and the/that fruit-DAT so bitter be-PST water-Poss

'and the/that fruit had such a bitter juice'

(Funeral Sermon and Prayer)

Table 3.3 summarizes all the article-like occurrences of the demonstrative $o z(>a z)$ in the Early Old Hungarian period. With such a low quantity of data it does not make much sense to draw charts and present statistics, but the overall number of determiners in proportion to the tokens of the manuscripts may be interesting as compared to the corresponding ratio found in later codices (e.g., those figuring in Table 3.4). ${ }^{8}$

\begin{tabular}{|c|c|c|c|c|}
\hline MS & Date & Tokens & $o z$ & $\%$ \\
\hline $\begin{array}{l}\text { Funeral Sermon and } \\
\text { Prayer }\end{array}$ & ca.1195 & 281 & 4 & 1.42 \\
\hline $\begin{array}{l}\text { The Königsberg } \\
\text { Fragment and Ribbons }\end{array}$ & end of 12 th $c$. - beginning of 13 th $c$. & 389 & 1 & 0.25 \\
\hline $\begin{array}{l}\text { The Old Hungarian } \\
\text { Lamentations of Mary }\end{array}$ & second half of $13^{\text {th }} \mathrm{c}$. & 145 & - & o \\
\hline Gyulafehérvár Lines & second half of $13^{\text {th }} \mathrm{c}$. & 51 & 1 & 1.96 \\
\hline Total & & 866 & 6 & 0.69 \\
\hline
\end{tabular}

The first texts of considerable length and thus suitable for syntactic investigation come from the first half of the Late Old Hungarian Period in the form of codices written in Hungarian. It is remarkable that the proportion of the morpheme $(o z>) a z$ in the first

\footnotetext{
8 Token numbers are always given on the basis of the original spelling of the manuscript, but without punctuation marks.
} 
extant codex is already $2.52 \%$, and this number is consistently rising as time goes by (see Table 3.4 in the following section).

\subsubsection{The use of the definite article in Late Old Hungarian}

For reasons discussed so far, the reconstruction of the earliest coherent synchronic system of determiners must focus on the first half of the Late Old Hungarian Period. Nevertheless, this period as a whole (1370-1526) cannot be discussed uniformly, considering that the use of the definite article in the earliest codices, which can be dated to the end of 14th century and the first half of the 15th century, is somewhat different from that of manuscripts from the beginning of the 16th century. The early manuscripts, the Jókai Codex and two further codices containing translations of the so-called Hussite Bible, are already long enough, they are uniform, narrative texts, each forming a closed corpus of its own. The Jókai Codex is the first extant, handwritten book in Hungarian. It is about the life and deeds of Saint Francis of Assisi, and is a 15th-century copy of the original translation from around 1370. The Hussite Bible is the first Hungarian Bible translation made between 1416 and 1441. It is preserved in three codices from which only two contain relatively early copies of the original translation: the Vienna Codex from 1450 (Old Testament books and the twelve minor prophets) and the Munich Codex dating to 1466 (the four gospels).

As has already been pointed out, due to the formal and positional equivalence and functional overlap (e.g. anaphoric use) between the Old Hungarian article and the demonstrative modifier which the article developed from, these determiners cannot be distinguished from each other merely on formal grounds-at least for today's reader. Apparently, the same morpheme corresponds to two different functions: sometimes it seems to behave as a demonstrative, sometimes as a definite article, and often it is impossible to decide between the two alternatives. It is therefore not surprising that in the descriptive literature on Old Hungarian there is a strong tendency to consider these early articles as "pre-articles" or "pronoun-articles" that belong to a special transitional word class with dual nature (Bakró-Nagy 1999:7; I. Galassy 1992:721-722). Nevertheless, contrary to earlier records, Late Old Hungarian sources are appropriate for a more sophisticated investigation: the definite article can be argued to be a fully grammaticalized category encoding definiteness on a syntactic level, since one can easily search for specific semantic and pragmatic contexts in which only an article can appear. For instance, the associative-anaphoric use of the definite article can be well attested as early as in the first codex:
(8) masod napon mykoron azon frater ewlne az aztalnal second day-SuP when that/same frater sit-COND.3SG the table-ADE neze zent ferencznek kepere
look-PST Saint Francis-DAT picture-POss-suP

'on the second day, when the same frater was sitting at the table, he had a look at the picture of Saint Francis'

(Jókai Codex 66) 
In the textual context of (8), there was no mention of any table before, but the scene is one of the convents of the monks where the protagonist, a certain preaching monk, has just arrived, as is reported in the preceding lines. The presence of a table in a building used by monks, or people in general, is naturally assumed. Considering that the object itself was not concretely mentioned before, the determiner preceding the noun cannot be a demonstrative (see also Egedi 2013 for further examples).

The other special context which has been claimed to be specific to articles and from which demonstratives are banned is the larger situation use. The Old Hungarian definite article, however, appears in this context only gradually, as inherently unique nouns (such as God, earth, moon, devil, etc.) resist being determined, similarly to proper names, which are also semantically definite. It can be generally observed that the use of the article in early codices had a more restricted use than in the subsequent stages of the language. The definite article is absent with nouns modified by a demonstrative, which encodes directly accessible reference, and in possessive constructions, in which case the referent of the possessed noun is existentially presupposed and is identified through its relation to the referent of the possessor. ${ }^{9}$ The presence of a demonstrative (9) or a possessor expression, either pronominal (10) or nominal (11), implies the definiteness of the noun phrase as a whole, and the use of the article is not yet required. It may be concluded that the definite article only appears when referential identification is not encoded otherwise. This means that what has to be obligatorily marked on the syntactic level by a definite article, already at the time of the first codices, is pragmatic definiteness.

(9) ez kener-ek-re

this bread-PL-SUB

'onto these breads'

(Jókai C. 76)

(10) èn keńèr-i-m-èt

I bread-POSS.PL-1SG-ACC

'my breads'

(Vienna C. 182)

(11) az èlèt- $\mathrm{n}^{\mathrm{c}}$ keńèr-è

the life-DAT bread-poss

'the bread of life'

(Munich C. 91ra)

The system of determiners has been changing quite rapidly. The use of the definite article proportionally increased already within the Old Hungarian period, as the results of an automatic query carried out in five normalized codices from the Old Hungarian Corpus indicates:

\footnotetext{
9 The identification and detailed analysis of definite contexts in which the article is still absent is discussed in Egedi (2013), which also provides several original data illustrating the various contexts.
} 
TABLE 3.4. The proportion of definite determiners $(a / a z)$ in five Old Hungarian codices

\begin{tabular}{lllll}
\hline Codex & Date & Tokens & a/az & \% \\
\hline Jókai Codex & after 1370/ca.1448 & 22,733 & 573 & $\mathbf{2 . 5 2}$ \\
Vienna Codex & after 1416/ca.1450 & 54,423 & 2,233 & $\mathbf{4 . 1 0}$ \\
Guary Codex & before 1495 & 21,714 & 1,390 & $\mathbf{6 . 4 0}$ \\
Könyvecse & 1521 & 8,745 & 623 & $\mathbf{7 . 1 2}$ \\
Kazinczy Codex & $1526-1541$ & 20,027 & 1,437 & $\mathbf{7 . 1 7}$ \\
\hline
\end{tabular}

The drawback of automatic queries like the one that yielded the figures above is that, besides adnominal modifiers/determiners, independently used demonstrative pronouns in nominative case also turn up in the search results. However, the well observable proportional increase of the morphemes a/az can only be due to the gradually increasing use of the definite article, that is, by its spreading into syntactic contexts in which it was not obligatory before. Note that this increase does not make its way equally fast in all the possible contexts: we observed that the spreading is more characteristic before generics and pronominal possessors, while the contexts presented in (9) and (11), nouns with demonstratives and lexical possessives, resisted the determiner throughout the period. ${ }^{10}$ At the same time, the automatically generated figures cannot be distorted to a large extent, since it is only the nominative pronouns that coincide with the adnominal demonstrative modifiers in form, and their number is supposed to be relatively low in a given text, as will be pointed out with respect to Table 3.5 in the next section.

The Modern Hungarian phrases that correspond to the Old Hungarian examples in (9)-(11), given below in nominative case for the sake of simplicity, look rather different, as the definite article has to be used obligatorily in these contexts. The article appears with the demonstrative modifier, before a pronominal possessor, and on the possessed noun in the case of a dative-marked possessor. ${ }^{11}$

(12) ez a kenyér

this the bread

'this bread'

(13) az én kenyer-e-i-m

the I bread-Poss-PL-1SG

'my breads'

10 The results of this research were presented on the 14th June 2012, at the conference "Exploring Ancient Languages through Corpora" in Oslo, see Egedi and Simon (2012). The figures in Table 3.4, however, have recently changed slightly, as the ongoing correction and improvement of the Old Hungarian Corpus continuously modify the results. Unfortunately, the proportional increase cannot be measured in the Middle Hungarian period, as the digitalization of Middle Hungarian records has just begun.

11 The variation between $a$ and $a z$ in Modern Hungarian is regular and purely morpho-phonetic, depending on whether the subsequent word begins with a vowel or a consonant. 
(14) az élet-nek a kenyer-e

the life-DAT the bread-poss

'the bread of life'

Despite these clearly observable differences, the definite article had undeniably grammaticalized to encode simple referential identification by the time of the first part of the Late Old Hungarian period, even if it did not expand immediately into all syntactic contexts in which it is used today. Moreover, for quite a long period, simple definite noun phrases and those modified by a distal demonstrative could not be distinguished merely on formal grounds (unless by intonation). Nevertheless, the article and the demonstrative can be assumed to occupy distinct structural positions, D and Spec,DP, respectively.

The emergence of the definite article may be reconstructed similarly to what Giuliana Giusti (2001: 167) proposes for the reanalysis of Latin ille in the Romance languages. As is shown in (15), ille, originally located in the specifier of the Determiner Phrase as a demonstrative, is reinterpreted as an element in D.

(15)

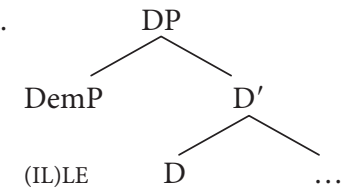

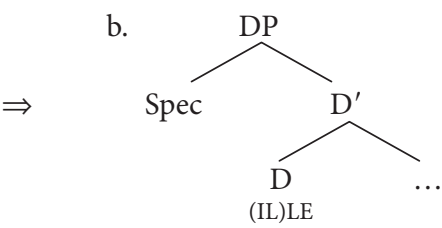

This kind of reanalysis perfectly conforms to the economy principles formulated by Elly van Gelderen (2004, 2008), the so called "Head Preference Principle", according to which speakers prefer to build structures where an element is merged directly into the head position instead of moving it to the specifier from below. ${ }^{12}$ If we accept that demonstratives are base-generated in a position lower than DP (see Giusti 1994, Bernstein 1997, and first of all Szabolcsi 1994b for distinguishing a D and a lower DET position in Hungarian), ${ }^{13}$ the above economy principle can be assumed to have been working in Old Hungarian when the definite article emerged. Demonstratives,

12 It is to be noted that the economy principles, which are often responsible for diachronic changes, express preferences rather than absolute principles and can be violated by prescriptive or innovative forces, as Elly van Gelderen argues.

13 The existence of a lower DET position is easy to justify in Modern Hungarian for there are constructions in which both determiner positions are filled, see (37a) in section 3.4.2. In Old Hungarian this claim remains hypothetical since pronominal possessors exclude the use of the definite article. However, we may find examples where a pronominal possessor expression combines with a determiner quantifier, and the latter is lower in the structure. Assuming that determiner quantifiers are generated in the same position as demonstratives in Old Hungarian as well, we may get indirect evidence for DET in Old Hungarian:

(i) es te menden èllènsegid èluèznèc

and you all enemy-Poss.PL-2SG perish-3PL

'and all your enemies perish'

(Vienna C. 2) 
associated with the grammatical features [+definite] or [+referential], left their original lower position and moved into the specifier of the DP. Since this movement took place frequently and regularly, the demonstrative element could be reanalyzed as a head rather than a phrase, and merged directly into the D head. Note that it is less economical to merge an element early in the syntax and then move it to a higher position than to procrastinate merging as long as possible (see van Gelderen's "Late Merge Principle").
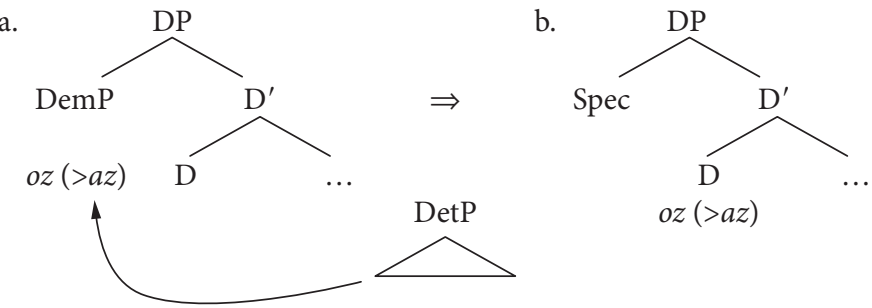

These two constructions may coexist, and they actually did co-exist for several generations in Old Hungarian, until new strategies for demonstrative modification emerged. However, in more archaic expressions (to be presented in 3.3.1) and in the very old construction with proximal demonstrative (e könyv 'this book'), this structural parallelism survives in Modern Hungarian as well.

\subsection{The DP-cycle}

According to a frequently cited generalization by Joseph Greenberg (1978), grammaticalization often takes the direction from demonstratives developing into articles, while the latter at a later stage might develop into a gender marker or a mere sign of nominality. It is true that the DP-cycle, in a typical case, involves demonstratives becoming articles, but at the same time, demonstratives must be renewed in some way. According to Elly van Gelderen's (2011) insightful overview of the phenomenon in several languages of the world, this renewal takes place by one of the following two strategies: it is frequently done either by reinforcing the old form with a locative adverb or by the incorporation of an additional demonstrative (e.g., an appositive pronoun) into the construction. So, in one of the strategies the new element comes from below, while in the other it incorporates rather high in the DP structure. Sometimes there is evidence for the simultaneous application of both strategies, as was the case in Old Norse (van Gelderen 2007: 295 and 2011: 207-208). It will be shown in the following sections that Hungarian also made use of at least two types of strategies after the definite article had grammaticalized and, in the case of the proximal demonstrative modifier, even the original structure was able to survive into Modern Hungarian. 


\subsubsection{The renewal of the demonstrative: reinforcement}

As has been shown in section 3.2.4, after the reanalysis of the demonstrative as a simple definite determiner, it can be merged directly into the $\mathrm{D}$-head. The two constructions, the original one, still open for deictic elements, and the newer one with the directly merged article, may coexist for a longer period. In Romance, however, new lexical items developed to fulfill the demonstrative function. An adverbial reinforcer (eccum) has been added to the phonologically weakened demonstrative head resulting in a new series of deictic elements (Giusti 2001: 170):14

(17)

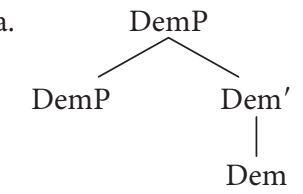

ECCUM- $\quad$ (I)STE

ECCUM- (I)LLE b.

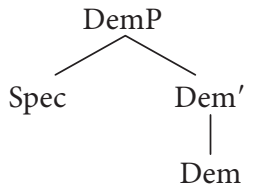

(EC)CU-E-STE (EC)CU-E-LLE

Old Hungarian can be assumed to have two homophonous structures, one for definite determination and one for demonstrative modification, as was presented in (16). If one looks at present-day Hungarian, it becomes obvious that the two constructions diverged in a different way than they did in Romance. The unmarked and most commonly used constructions with demonstrative modifiers involve determiner doubling, which suggests that demonstrative modification has been renewed by readding a deictic element to the phrase headed by the article. Nevertheless, this grammaticalization path was not smooth and linear: more than one strategy was promptly available from the beginning and what happened in reality is only a shift in proportions between the possible constructions rather than one following the other.

In Old Hungarian, two pairs of demonstratives can be found, namely ezen/azon 'this/that' and imez/amaz 'this/that', which probably developed from simple demonstrative pronouns by a process of reinforcement, similarly to what has been presented in (17). Before going into the details, four examples are provided to illustrate the use of the individual morphemes.

(18) Azert mert èzen èmber harom nèuèckèl nèuèztètic that-for because this man three name-PL-INs be.named-3sG 'Because this man is called by three names'

(Vienna C. 234)

(19) Azon idọben az kÿralnak uduaraba uala eǵ uitez that time-INE the king-DAT court-POSS-ILL be-PAST one hero 'In that time there was a hero in the king's court'

(Kazinczy C. 45r)

14 The individual demonstrative systems of modern Romance languages vary considerably in several respects, so (17) should only be considered as a schematic representation to model how certain demonstratives developed in these languages. 
(20) veeseetọ óketh imez palotaaban

throw-SBJV-2PL them this palace-INE

'throw them into this palace'

(Sándor C. 12v)

(21) tawol legen te telled hogy amaz embert zeressed

far be-SBJV-3SG you ABL-2SG that that man-ACC love-SBJV-2SG

kyt míndenbe ellensegesth vallaz

who-ACC everything-ILL enemy-like have-2SG

'Beware of loving that man who is your enemy in everything' (Lobkowicz C. 297)

As for the morphemes ezen/azon 'this/that', neither of the standard etymological dictionaries of Hungarian ${ }^{15}$ can provide precise information as to how these demonstratives were created. The morpheme ezen/azon 'this/that' is claimed to have been formed by augmenting the basic $e z$ with a pronominal derivational suffix - $n$ (EWUng 62 and 345, TESz I. 819 also adds that this derivational suffix has an emphasizing role). The original function of this reinforced pronoun (and pronominal modifier) must have been strong identification, which is indicated by the fact that in the early Jókai Codex, out of 15 occurrences of azon, 13 undoubtedly mean 'the same' rather than simply 'that' and it is regularly used as the translation of the Latin identity marker idem. Its semantic property of identification, however, bleached quite rapidly and reduced to anaphoricity, as suggested by the emergence and use of ugyan 'same' in combination with pronouns and adverbs to express referential identity (e.g., ugyaz-azon, ugyan-az 'the same', ugyan-ott 'the same place' lit. 'same-there').

According to the etymological dictionary (EWUng 32, 318, and 608), the morphemes imez/amaz 'this/that' are compositions formed by a syntactic fusion, in which the first member derives from ime and ám 'look, behold', and has a reinforcing function (Verstärkungselement). ${ }^{16}$ Note that the form imez 'this' is later replaced by eme(z) and only this newer form survives in standard Modern Hungarian, although forms beginning with $\mathrm{em}$ - are only attested from 1628 on.

The morphemes ezen/azon 'this/that' are claimed to have already existed in ProtoHungarian (D. Mátai 2003: 217), while the compounds imez/amaz 'this/that' only emerged in Late Old Hungarian (G. Varga 1992: 489). Stipulations on their use before the written documents do not have much sense of course. What can be stated with certainty is that the latter pair is indeed a more recent formation, since ezen/azon are clearly attested in the Königsberg Fragment and Ribbons (see section 3.2.3 for the source), while no imez/amaz can be found either in the Early Old Hungarian records or in the first codices of Late Old Hungarian.

15 Their standard abbreviations are TESz (A magyar nyelv történeti etimológia szótára) and EWUng (Etymologischen Wörterbuch des Ungarischen), see Benkő (1964-1987) and Benkő (1993), respectively.

16 These latter reinforcing elements are themselves claimed to derive from more ancient reinforced demonstratives. 
In the grammatical descriptions cited, no concrete numerical data are given or even estimated as to the frequency of these reinforced determiners in the texts during the Old Hungarian period. As our research will demonstrate, their rate of recurrence is quite low at this time; they are almost exceptional, at least in comparison with the large mass of "original" demonstratives. In Table 3.5 the results of an automatic query are provided (carried out with the aim of exhaustive listing, thus also manually revised). The query involved ten already normalized codices of the Old Hungarian Corpus (comprising 17,55540 tokens). ${ }^{17}$

\section{TABLE 3.5. Demonstrative determiners (including articles) in ten normalized codices of the Old Hungarian Corpus}

\begin{tabular}{lllllllll}
\hline Codex & Date & Tokens & e/ez & a/az & ezen & azon & ime $(z)$ & ama $(z)$ \\
\hline Jókai Codex & a1370/c.1448 & 22,733 & 272 & 573 & 5 & 15 & - & - \\
Vienna Codex & a1416/c.1450 & 54,423 & 407 & 2,233 & 6 & 32 & - & - \\
Birk Codex & 1474 & 2,142 & 22 & 130 & 1 & 6 & - & - \\
Festetics Codex & $1492-1494$ & 23,700 & 77 & 234 & - & 11 & 1 & - \\
Guary Codex & before 1495 & 21,714 & 450 & 1,390 & 13 & 2 & - & 3 \\
Könyvecse & 1521 & 8,745 & 85 & 623 & - & 2 & - & 1 \\
Kazinczy Codex & $1526-1541$ & 20,027 & 259 & 1,437 & 3 & 12 & 5 & 3 \\
Czech Codex & 1513 & 10,998 & 88 & 239 & - & - & - & - \\
Bod Codex & first half of & 10,084 & 119 & 554 & - & 4 & - & 2 \\
& the 16th c. & & & & & & & \\
Miskolc Fragment & 1525 & 974 & 3 & 38 & - & - & - & - \\
SUM & & 17,5540 & 1,782 & 7,451 & 28 & 84 & 6 & 9 \\
\hline
\end{tabular}

The problem mentioned in 3.2.4. shows up again, inasmuch as the pronominal uses of $e z$ and $a z$ also turn up in the hits of the query, which slightly distorts the data. Luckily enough, only pronouns in nominative case are concerned. In the case of the reinforced demonstratives the problem could be solved, as the low number of the hits made it possible to sort out the pronominal occurrences manually; the table only includes the modifier uses as expected. To get a rough impression of how strongly the pronouns in nominative alter the proportions, another testing has been carried out in two codices that also have morphological annotations. According to this research, in the Guary Codex, out of all the occurrences of $e / e z$ and $a / a z$, only $6.21 \%$ can be analyzed as a pronoun instead of a determiner, while in Jókai Codex this proportion is even lower, namely $4.85 \%$. Accordingly, if we assume that the pronouns out of all the hits for $e / e z$ and $a / a z$ in the above ten codices do not exceed a ratio of $5-6 \%$ in general, the

\footnotetext{
17 As the Székelyudvarhely Codex is only partially normalized, it has been ignored in this calculation. See the Appendix of this volume for more information about the structure of the Old Hungarian Corpus and the different text processing levels of the manuscripts.
} 
significant difference between the occurrences of old (e/ez, a/az) and new, reinforced demonstratives (ezen, azon, imez, amaz) remains nearly unaffected.

The strikingly high number of $a / a z$ is, of course, due to the fact that this column comprises both the distal demonstrative modifiers and the articles. Furthermore, it can clearly be observed that among the reinforced determiners, azon 'that' was the most commonly used. It is quite understandable, since formal disambiguation was only needed in the case of constructions involving a distal demonstrative. What the overall picture shows us, however, is that the use of these reinforced demonstratives had not yet diffused. This situation will considerably change in Middle Hungarian, as data drawn from secondary literature suggests (see section 3.4.1).

\subsubsection{The renewal of the demonstrative: doubling}

The noun phrase construction involving a demonstrative modifier renewed in another way as well by the emergence of a new pattern during the 16th century (the beginning of the Middle Hungarian period). In this structure a sort of determiner doubling can be observed, viz. the simultaneous spelling out of the demonstrative and the article. This is the pattern that is commonly used in Modern Hungarian (see (12)).

Did we thus arrive at the construction that is also used in the present-day language? The first impression suggests that this is the case: the new doubling configuration may be analyzed as the double filling of the functional projection for definiteness. The demonstrative is moved to and spelled out in the specifier position, while the determiner in article function is the head of the DP (22).

(22)

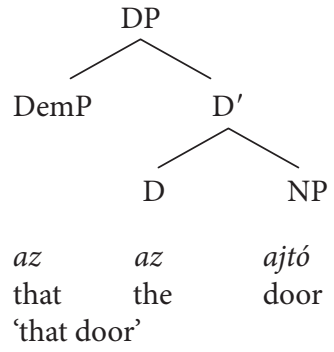

Demonstrative modifiers in these doubling constructions behave in a rather peculiar way in Middle as well as in Modern Hungarian, that is to say, they are not prototypical deictic determiners. Demonstratives co-occur with the definite article, and unlike other modifiers, they agree in number and case with the head noun.
a. ez-ek az ajtó-k this-PL the door-PL
b. az- $\mathrm{t}$
az ajtó-t
c. az-ok-at
az ajtó-k-at
that-ACC the door-ACC that-PL-ACC the door-PL-ACC 'these doors' 'that door' 'those doors'

Moreover, a doubly filled functional projection (DP in this case) is also atypical and, in a generative framework, considered to be against the basic economy principles 
of syntax. These facts would suggest that the demonstrative and the noun phrase beginning with the article are actually two juxtaposed DPs, which can be represented in the phrase structure as an adjunction structure. In the rest of this section it will be demonstrated that both analyses are justified: one will account for Modern Hungarian, while the other for the Middle Hungarian data.

As regards Modern Hungarian, there are good reasons to assume that the demonstratives $e z / a z$ 'this/that' are in fact located in the specifier position of the DP projection, rather than being adjoined to it, even though the definite article is also spelled out in the head of the same phrase. Nothing can intervene between the demonstrative and the article, the two determiners also form a prosodic unit, and by dropping the article the construction becomes ungrammatical. ${ }^{18}$ Observing the historical data, however, we can conclude that the conditions were slightly different when this pattern arose in the Middle Hungarian period. In the 16th and 17th centuries, the newly added demonstrative appears to link more loosely with the noun phrase than it would do today. Demonstratives can be separated from the rest of the construction by a variety of elements, e.g., conjunctions, various particles, sometimes by the verb itself. In these cases, the sequence of the demonstrative and the definite article is evidently broken.

As has been mention earlier, the digitalization of Middle Hungarian records has just begun, so the following data are all drawn from the descriptive grammar of Simonyi (1914: 122-123). The examples come from the first half of the 17th century, showing how the sequence of the determiners is interrupted, for instance, by a scalar particle (24a), by an interrogative particle (25a), or by a modal verb and a conjunction (26a). For explicitness, (24b)-(26b) demonstrate how these phrases would look in Modern Hungarian so that the difference between the two word orders can clearly be observed. ${ }^{19}$

a. azok is az esküvések
those also the swearings
'also those swearings'

b. azok those the swearings also 'also those swearings'

(From the letters of Péter Pázmány)
a. Mit választasz inkább? ezt-e
a pénzt?
what choose-you rather? this.ACC-Q the money-ACC

'What do you prefer to choose? This money?'

(Káldi Preachings)

b. ezt a pénzt-e

this.ACC the money.ACC-Q

18 Hereby we follow the analysis of Huba Bartos (2000, 2001), also adapted by É. Kiss (2000); however, the placement of the demonstrative modifier in the specifier of the DP was first suggested by Kenesei (1994: 295).

19 The peculiarities of the Middle Hungarian demonstrative are the central topic of a closely related paper (Egedi, forthcoming). In that study, my aim was to account for the word order variation at the nominal left periphery, while here the main focus is on the renewal of the demonstrative system. However, as the two complement each other, the data and the analyses necessarily overlap and some arguments are repeated. 
It is also remarkable that in Middle Hungarian the combination of this determiner doubling construction with dative-marked possessors may result in a word order (26a) different from what would be grammatical in Modern Hungarian (26b).

(26) a. ar-rul is az bibliá-nak rész-é-rül

(Péter Pázmány) that-DEL also the Bible-DAT part-POSS-DEL 'also about that part of the Bible'

b. a Bibliá-nak ar-ról a rész-é-ról is the Bible-DAT that-DEL the part-POss-DEL also

It is exactly the combination of possessive constructions with demonstratives that indicates how the structure of determiner doubling changed in time. Hungarian has (and has always had in its documented history) two possessive constructions. In one of them the possessor is dative-marked, in the other the possessor is unmarked. Although the dative marked possessor can be extracted from the noun phrase, or else, generated outside of the noun phrase as an external possessor (for the conditions of the possible configurations in Modern Hungarian, see É. Kiss, forthcoming), the two possessive constructions show no difference in meaning. In Old Hungarian, if the dativemarked possessor is generated internally, it seems to end up in the same position as the unmarked form, that is, in the specifier of the DP. Both constructions exclude any further determination and do not combine with demonstratives that also target Spec,DP.

What the Middle Hungarian data suggest altogether is that the determiner doubling construction is the outcome of an adjunction operation, where the demonstrative pronoun as a whole adjoins to the DP headed by an article, thus the structure differs from the one proposed in (22):

(27)

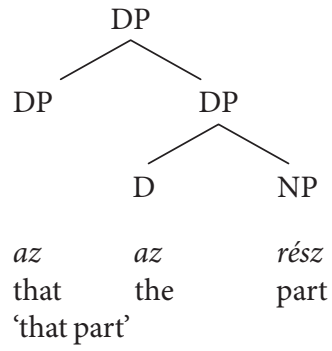

That is why the combination of Middle Hungarian demonstratives with possessive constructions results in the word order presented in (26a). To account for the reverse word order of the nominal left periphery in Modern Hungarian, according to which dative-marked possessors always have to precede the demonstrative modifiers (26b), it is plausible to assume that the adjoined determiner phrase containing the demonstrative has again been integrated into the DP domain. Note that this is in accordance with Elly van Gelderen's (2008: 250) third universal economy principle. 
The so-called "Specifier Incorporation" states that elements coming from outside tend to be a specifier rather than an adjunct.

The leftmost adjunction site of the DP was open for both dative-marked possessors and demonstratives, but the fact that demonstratives were chosen for incorporation might have been facilitated by the already present patterns with extracted and external possessors. At a later point of the process, the adjunction of the regularly appearing dative-marked possessors may have been reanalyzed as an internal topicalization, producing a new layer of the extended noun phrase-in line with what É. Kiss (2000) proposes for present-day Hungarian.

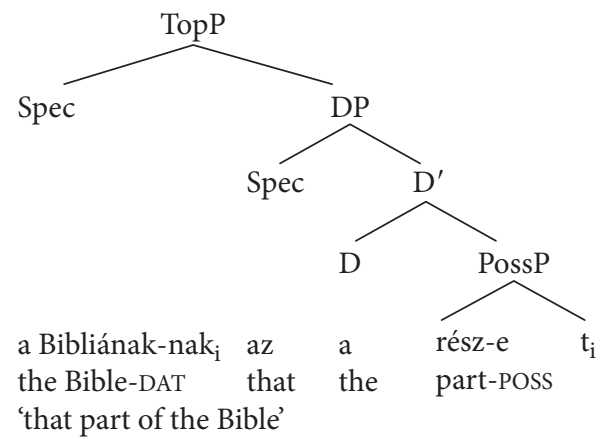

This chain of changes finally led not only to the present-day word order on the nominal left periphery but also to the rather atypical behavior of the demonstratives, viz. their appearance in a doubly filled DP projection and their somewhat exceptional morphology of being marked for case and plurality, in spite of their modifier status.

It is to be noted that although the use of this doubling construction is the primary means of expressing demonstrative modification in present-day Hungarian, it practically does not appear before the Middle Hungarian period. As regards its spreading, the next section will mostly rely on the figures provided in a recent paper by Adrienne Dömötör (2008). However, for lack of a considerable large digitized corpus similar to the Old Hungarian Corpus, it is impossible to determine at this point of the research when the above proposed structural reintegration of demonstratives took place. (Manual search for such constructions is a hopeless task considering that combination of demonstratives and possessives is an overall infrequent phenomenon for obvious semantic reasons.)

\subsection{Competing strategies}

Following the grammaticalization of the definite article, the demonstrative system has been renewed at least by two kinds of strategies in Hungarian. On the one hand, two pairs of reinforced demonstratives could be identified, one of them appearing already in the Early Old Hungarian period. On the other hand, a new pattern also emerged at 
the beginning of the Middle Hungarian period, in which an additional demonstrative adjoined to the noun phrase headed by the definite article. As will be shown in the remainder of this chapter, the original strategy has also been preserved and is still operative to some extent.

The new strategies emerged gradually, reinforcement being the first in Old Hungarian, followed by determiner doubling in Middle Hungarian. Their upcoming success cannot be presumed on the basis of the digitized Old Hungarian Corpus, as the crucial period with respect to their spreading seems to be the Middle Hungarian stage. Importing Middle Hungarian records into our corpus has just begun and, consequently, no quantitative data can be provided for the distribution and spreading of the various constructions involving demonstrative modification. Luckily enough, Dömötör (2008) addressed the question of these constructions, and her research can serve as a good basis for our investigations. The corpus, as she informed me in a personal communication, was not a digital one, and includes text excerpts from various types of genres. It contains 200,000 characters per century, which means that the corpus amounts to approximately 100,000 tokens altogether.

\subsubsection{Data from Middle Hungarian}

The point of view according to which Dömötör (2008) arranged and interpreted her data is different from our own: she was more interested in the opposition of agreeing vs. non-agreeing demonstratives and examined the data in this respect: whether or not there is (case and number) agreement on the demonstrative modifier.

TABLE 3.6. The proportion of constructions with demonstrative modifiers (Figures from Dömötör 2008:24) ${ }^{20}$

\begin{tabular}{llllc}
\hline & 16 th c. & 17th c. & 18th c. & For the entire period \\
\hline Agreeing Dem + Art + N & $5.9 \%$ & $19.6 \%$ & $34.9 \%$ & $20.3 \%$ \\
Non-agreeing Dem + N & $94.1 \%$ & $80.4 \%$ & $65.1 \%$ & $79.7 \%$ \\
\hline
\end{tabular}

Table 3.6 shows us quite explicitly how the determiner doubling construction ("Agreeing Dem + Art + N" in Dömötör's table) consistently spread during these centuries. Note, however, that there is a very important piece of information hidden in this table. The rising percentage does not only contrast with the old constructions (ez/az N). The lower line of the table also includes the nouns modified by ezen, imez, etc., that is, all the demonstratives-original and reinforced-that show no agreement when used as a modifier. An additional table not cited here suggests that the frequency of

\footnotetext{
20 The table, originally compiled in Hungarian, is not only translated here but also slightly modified for convenience.
} 
the pair ezen/azon 'this/that' also significantly increased, but precise data concerning the proportion of reinforced demonstratives with respect to the original constructions and to determiner doubling cannot be obtained on the basis of Dömötör's figures.

There is another very interesting phenomenon that can be observed in connection with the doubling construction. The spread of the pattern does not show the same rate in the case of the proximal demonstrative as in the case of the distal one. As the figures in Table 3.7 indicate, spreading of the doubling constructions with proximal $e z$ is definitely slower than that with the distal demonstrative, and the constructions are far less frequently attested if the entire period is considered. It is highly reasonable to assume that this difference of percentage can be due to the fact that the proximal demonstrative $e z$ differs from the definite article in its form, causing no ambiguity at all.

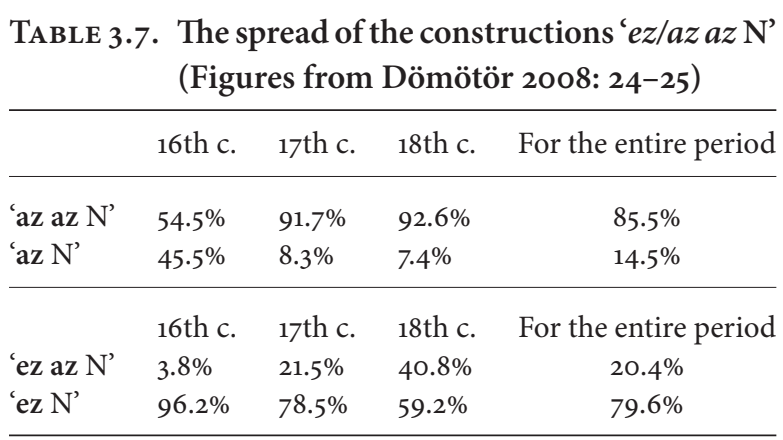

As has been mentioned, Dömötör's calculation has been built on a representative corpus of considerable size, but still, this collection of data cannot be large enough, due to the limits of manual work. Hopefully, by the extension and improvement of our digitized corpus, the percentages in Table 3.7 will be either more justified or will need to be modified. Furthermore, the proportional spreading of reinforced determiners should also be established. It would be really valuable to understand the mechanism of such competing strategies: what prevents a syntactic strategy (reinforcement) from triumphing over another one (doubling) in spite of the fact that it emerged much earlier and seems to have perfectly accomplished the task, viz. the disambiguation between demonstrative modification and simple definiteness. What made the younger, determiner doubling strategy become the winner?

\subsubsection{Modern Hungarian distribution of demonstrative modifiers}

In Modern Hungarian, all the constructions involving demonstrative modifiers that have been discussed so far are still available, but in a completely different proportion than in Old or Middle Hungarian. The only construction that has been lost is the type az ajtó 'that door', which is exclusively used to express simple definiteness today 
('the door'). ${ }^{21}$ In what follows, the uses and properties of the constructions in Modern Hungarian will be summarized and classified into two different groups.

\section{Determiner doubling construction: ez/az a vélemény 'this/that opinion'}

This is the most common type in Modern Hungarian, the unmarked construction to express demonstrative modification. The demonstrative modifier within the construction (ez/az 'this/that') is morphologically inflected for number and case in agreement with the lexical noun (29). Moreover, postpositions that do not take an oblique case are also repeated on them (30).

(29) Nem ismerjük ez-ek-et a vélemény-ek-et.

not know-1PL this-PL-ACC the opinion-PL-ACC

'We do not know these opinions.'

(30) Nem aggódunk ez-ek miatt a vélemény-ek miatt. not worry-1PL this-PL about the opinion-PL about

'We do not worry about these opinions.'

Spelling out the article is obligatory in this construction, and the two determiners (the demonstrative modifier and the definite article) are strictly juxtaposed. The fixed position of the demonstrative in the specifier of the DP is very likely, since the doubling construction cannot be combined with a nominative/unmarked possessor. Unmarked possessor expressions are assumed to occupy the same structural position, i.e., the specifier of the DP (see É. Kiss 2000: 134). ${ }^{22}$
a. a miniszter
vélemény-e $\quad+$
the minister opinion-Poss
'the minister's
opinion'
ez a vélemény
+ this the opinion $\Rightarrow$
$+\quad$ 'this opinion'
b. ${ }^{*}$ a miniszter ez a vélemény-e
the minister this the opinion-poss
c. a miniszter-nek ez a vélemény-e
the minister-DAT this the opinion-POss
'this opinion of the minister's'

21 Exceptions can be found, of course: the old demonstrative meaning of az survived in a few temporal expressions, such as az-nap 'that day' (instead of 'the day'), and in other fixed expressions, e.g., a tekintet-ben 'in that respect' (instead of 'in the respect').

22 There are two types of possessor expressions in Hungarian: a dative-marked and a nominative-marked (or preferably unmarked), with no actual difference in meaning. They only differ in one respect, viz. the syntactic position of the possessor expression. With dative-marked possessors we have a more extended DP as dative-marked possessors co-occur with the definite article and they can even be extracted (see Szabolcsi 1994: 180-181, É. Kiss 2000). In both possessive constructions the head noun is always marked for being possessed by a suffix. 
The construction has been shown to have developed in the Middle Hungarian period and to have spread only gradually until it became dominant today. When the construction emerged, the demonstrative behaved more like the host of an appositive lexical DP, with the lexical DP adjoined to it. This structure resulted in word orders that would be ill-formed in present-day Hungarian with demonstratives preceding the possessor expression (see (26a) above).

II. A stylistically marked type: e/ezen/azon/eme/ama vélemény 'this/that opinion'

This type is stylistically marked in Modern Hungarian (official, mannered even), or sounds rather archaic, and is completely missing in colloquial registers. In this pattern, the demonstrative determiner (e/eme/ezen 'this' or $a m a^{23} / a z o n$ 'that') and the article mutually exclude each other (32). There is no plural and case marking on the demonstrative (33), and postpositions are not repeated either (34).

$$
\begin{aligned}
& * \text { e/ezen/azon/eme/ama a vélemény } \\
& \text { this/that the opinion }
\end{aligned}
$$

(33) Nem ismerjük e/ezen/azon/eme/ama vélemény-ek-et. not know-1pl this/that opinion-PL-ACC 'We do not know these/those opinions.'

(34) Nem aggódunk e/ezen/azon/eme/ama vélemény-ek miatt. not worry-1pl this/that opinion-PL about 'We do not worry about these/those opinions.'

These constructions can freely be combined with both the unmarked and the dativemarked possessors.

(35) a. a miniszter e/ezen/azon/eme/ama vélemény-e the minister this/that opinion-Poss 'this opinion of the minister's'

b. a miniszternek e/ezen/azon/eme/ama vélemény-e the minister-DAT this/that opinion-POss 'this opinion of the minister's'

To account for all these properties, it must be assumed that the position of these archaic demonstratives is lower in the construction and they are only raised to D optionally. Anna Szabolcsi (1994b) has argued that Hungarian determiners fall into two distinct categories syntactically. Only the article belongs to the category $\mathrm{D}$, the others originate in a lower DET position. Indeed, these archaic demonstratives seem to occupy the same position as the determiner quantifiers in (36a).

\footnotetext{
23 The longer forms ending in - $\mathrm{z}$ (emez/amaz) are only used as pronouns, as far as standard Modern Hungarian is concerned. Dialectal variation, of course, cannot be excluded.
} 
(36) a. a hercegnő minden/melyik/valamennyi/egyik kívánság-a the princess every/which/all/one ${ }_{+\mathrm{SPEC}} \quad$ wish-poss 'all/which/one of the princess' wishes'

b. a hercegnő e/eme/ezen kívánság-a the princess this wish-poss 'this wish of the princess'

The low position of the determiners can also be observed when they are combined with a pronominal possessor (37a). In this case a phrase-initial article also appears, but this can also be due to the fact that spelling out the personal pronoun (only used for contrast or emphasis) is impossible without the article. The same construction with a null pronominal is not acceptable (37b).
a. a ti e/eme/ezen kívánság-a-i-tok

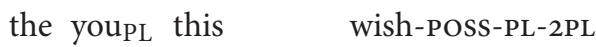 'these wishes of yours'
b. *a e/eme/ezen kívánság-a-i-tok the this wish-POSS-PL-2PL

It can be seen that these stylistically marked patterns derive from the Old and Middle Hungarian constructions involving a reinforced demonstrative. Unlike $e z / a z$ 'this/that' of the doubling constructions, which first appeared as adjoined constituents, these demonstratives are base-generated below the DP and may as well remain in situ. On the basis of its similar behavior today, the demonstrative $e$ 'this' in its very short form can be grouped together with the reinforced derivatives, but it must be pointed out that $e$ 'this' is the successor of the oldest constructions of the type $e(z) / a(z)$ ajtó 'this/that door' and was only able to survive because of its unambiguous shape. In contrast, its distal pair $a(z)$ 'that' did not survive as a demonstrative modifier but transformed to encode the definite article.

\subsubsection{Some dialectal peculiarities: the complete integration of demonstratives}

As reported in some dialectal grammatical descriptions, plural agreement in doubling constructions may be absent in certain varieties of Hungarian. The data on the left (marked by a letter a) show the dialectal records, while the corresponding examples on the right (b) indicate how these phrases would be formed in standard Modern Hungarian. The phenomenon has been attested in the north-eastern dialectal region of the country (Kálmán 1966: 85):
a. ez-t
a ház-ak-at
this-ACC the house-PL-ACC 'these houses'
b. ez-ek-et a ház-ak-at this-PL-ACC the house-PL-ACC 'these houses'


This pattern is also characteristic in the so called Palóc dialect (Király 1991: 538; É. Kiss 2006: 530):

(39) a. Haggyuk ez-t a gyerek-ek-et táncolni! let.SBJV.1PL this-ACC the child-PL-ACC dance-INF 'Let these children dance!'

b. Hagyjuk ez-ek-et a gyerek-ek-et táncolni! let.SBJV.1PL this-PL-ACC the child-PL-ACC dance-INF 'Let these children dance!'

Moreover, in a certain isolated dialect spoken in the village of Domokos (situated in the historic Szolnok-Doboka region, today's Dămăcuşeni in Northern Romania) both plural agreement and case marking have been lost on the demonstrative, which may be a clear sign of a more perfect integration of the modifier into the noun phrase structure (the data are cited from Németh 1913: 67):

(40) a. az az ember-ek nem jó hâré mennek that the man-PL not good place-sub go-3PL 'those men are not going to the right place'

b. az-ok a ember-ek that-PL the man-PL 'those men'

(41) a. add az a gyermek-nek b. add an-nak a gyermek-nek give that the child-DAT give that-DAT the child-DAT 'Give (it) to that child.' 'Give (it) to that child.'

These isolated records, collected from secondary literature and dating to a period about a century ago, are only cited to show a possible step in the DP-cycle in Hungarian. In these dialects, a more advanced incorporation of the demonstrative modifier can be observed. In the dialect of Domokos, the two determiners seem to have completely fused, and as far as I see there is no point in analyzing them as two separate elements.

\subsection{Summary}

In this chapter several stages of the DP-cycle have been discussed as well as their structural consequences in Hungarian. It has been presented and analyzed how the marking of definiteness changed in time and how the emergence of the definite article and its functional spreading reshaped the nominal left periphery from the first written sources to the present-day.

It has also been shown that the renewal of the demonstrative system involved at least two types of strategies in Hungarian, reinforcement as well as determiner doubling, 
whereas the old construction is also preserved to some extent. The reinforcing strategy produced two new series of demonstrative pronouns, while the determiner doubling phenomenon entailed a long-term structural reanalysis at the nominal left periphery. The word order change that can be observed between Middle and Modern Hungarian, in the cases where demonstratives are combined with dative-marked possessor expressions, indicates that demonstratives first linked with the noun phrase headed by the definite article by means of adjunction, but later were incorporated into the DP-internal specifier position.

The competing strategies of demonstrative modification coexisted from the Middle Hungarian period onward and their descendant constructions survive in presentday Hungarian as well, though they are used with a different degree of markedness. Dialectal data were also considered to show that in a few varieties of Hungarian a further step of demonstrative integration can also be observed. 